\title{
JGI Activity Reports: Chimpanzee Sanctuaries in Africa
}

$\operatorname{AUTHOR}(S)$ :

Goodall, Jane

CITATION:

Goodall, Jane. JGI Activity Reports: Chimpanzee Sanctuaries in Africa. Pan Africa News 1995, 2(2): 4-6

ISSUE DATE:

1995-10

URL:

http://hdl.handle.net/2433/143329

RIGHT:

Copyright (C) Pan Africa News. 


\section{JGI ACTIVITY REPORTS: CHIMPANZEE SANCTUARIES IN AFRICA}

Throughout their range in Africa chimpanzee numbers are declining. The primary reasons vary from country to country, but habitat destruction and the bushmeat trade are the two biggest threats to survival. There is also some deliberate shooting of mothers in order to take their infants for the despicable trade in live animals.

JGI (Jane Goodall Institute) has been 
officially approved in Tanzania, the Congo Republic and Burundi to care for infant orphan chimpanzees who have been confiscated from hunters, markets and pet owners by government officials. Additionally we are helping to look after orphans in Uganda and Kenya.

The Kitwe Point Sanctuary in Kigoma is almost ready (as I write this in September) to receive the four young chimpanzees who were confiscated from Zairean hunters in February 1994 (Originally there were six but two died; one was too far gone when handed over and we lost the other very recently from a sudden illness). We have received, right from the start, wonderful cooperation and support from all the relevant officials in Kigoma.

The Tchimpounga Sanctuary in the Congo Republic was built by Conoco, the oil company. Conoco continues to make an annual contribution which helps with the costs. Our JGI representative Graziella Cotman is helped by Jean Maboto, Ludovic Rasaba and four other keepers to care for the 48 orphans now at this sanctuary. This is a major undertaking and represents a major committment on our part. Since the sanctuary was opened four years ago only two infants have died, both of sickness.

Brazzaville Zoo. Infant chimpanzees confiscated by government officials in Brazzaville initially are cared for by JGI staff at the Brazzaville Zoo. We also care for the three adult males who cannot be moved to join the younger chimpanzees (and two adult females) at Tchimpounga. Currently there are two infants along with the adult males in Brazzaville. Many people know of Gregoire, the very old male chimpanzee who was completely emaciated and almost entirely hairless when I met him five years ago. Thanks to a generous donation he has now moved into a more spacious room with an outdoor "patio". This occurred in August when Dr. Cedric Dumont was visiting and was able to sedate him for the move. Gregoire, who is at least 50 years old and has been alone in his bare cage for over 40 years now plays with the four year old Bob.

The Half Way House, Burundi. JGI has maintained a presence in Burundi for a number of years. Our intention was to cooperate with the government to develop chimpanzee ecotourism and we are still working with a Burundian director to study and habituate chimpanzees of Kibira National Park in the north of the country. However, our attention was soon directed to the plight of a number of young "pet" chimps who had outgrown the "cute" stage and were languishing in cramped and unsuitable cages.
And then we were told about chimp infants (mostly from Zaire) being sold illegally in the streets. Humanitarian instincts were roused and the government agreed to clamp down on the illegal chimp traffic. This meant JGI was more or less pressured into building temporary accomodations for the orphans which were named the "Half Way House". As yet, for a variety of reasons, we have not been able to raise the money 'for a permanent sanctuary. Because so many chimpanzee infants were handed over conditions at the Half Way House became crowded and totally inappropriate.

In June 199510 of our 20 orphans from Burundi were successfully moved to the new Sweetwaters Chimpanzee Sanctuary in Kenya which was built by Lonrho. They have settled in well. We hope the other 10 can join them once the necessary permits have been obtained and all 20 will eventually be on loan from the Burundi government.

JGI also contributes to the care of orphan chimpanzees in Uganda, at the Entebbe Wildlife Education Centre and the Lake Edward Chimpanzee Sanctuary, recently set up to care for 11 of the orphans from Entebbe. There are other chimpanzee sanctuaries in Africa, notably Chimfunshi in Zambia, Baboon Islands in the Gambia and the Conkuati River sanctuary in the Congo. There are thus between 200 and 300 chimpanzee orphans being cared for in sanctuaries in Africa. They are in enclosures surrounded by electric wires or walls, on islands or in temporary housing. And they will rely on human care for the rest of their long lives because chimpanzees almost never can be put back in their natural habitat. They have become dependent on people and would be likely to wander into a village where they would probably be caught or killed. Moreover, because wild chimpanzees are territorially aggressive newcomers would probably be attacked or most likely killed. This is why Stella Brewer's attempt to release the Gambia orphans in chimp habitat in the Senegal had to be abandoned. It means that even though ex-captives can be taught to forage and live in the forest by human caretakers, rehabilitation in the wild is only feasible when they can be released into an area that is uninhabited (by chimps and humans) and that will provide sufficient suitable foods. Chimpanzees were released into such a place Rubondo Island in the Tanzanian section of Lake Victoria - more than 20 years ago. The descendants of those who survived now live there, completely wild.

Often JGI is criticized for spending money on orphans rather than putting the funds into preservation of the wild chimpanzees and their 
orphans rather than putting the funds into preservation of the wild chimpanzees and their habitat. Or we are asked how we can justify spending money on animals when people are starving. We are doing what we feel we must. We are certainly trying to help conservation; we are cooperating with governments, helping to develop eco-tourism as a source of much-needed foreign exchange. And we are working with villagers, providing jobs and developing conservation education programs. The chimpanzees serve as a focus for such education so that local people, especially children, start to realize just what amazing beings chimpanzees are. We also try to explain how the plight of humans and nonhumans in Africa is linked. If the forests and the animals go the desert will creep across the land and people will be doomed also.

Over and above this I cannot turn my back on individuals. My research has always focused on the importance, the value, of the individual. Once we are prepared to accept that it is not only humans who have personalities, not only humans who are capable of reason and above all not only humans who have emotions and can suffer, mentally as well as physically, our attitude to many of the non-human beings with whom we share the planet changes.

Jane Goodall 